\title{
Evaluating expansion strategies for startup European Union dairy farm businesses
}

\author{
R. McDonald, ${ }^{*}{ }^{1}$ L. Shalloo, ${ }^{*}$ K. M. Pierce, $\dagger$ and B. Horan* \\ *Animal and Grassland Research and Innovation Centre, Teagasc Moorepark, Fermoy, Co. Cork, Ireland \\ †School of Agriculture and Food Science, University College Dublin, Belfield, Dublin 4, Ireland
}

\begin{abstract}
A stochastic whole-farm simulation model was used to examine alternative strategies for new entrant dairy farmers to grow and develop dairy farm businesses in the context of European Union (EU) milk quota abolition in 2015. Six alternative strategies were compared: remain static, natural growth expansion, waiting until after EU milk quota abolition to expand, a full-scale expansion strategy without milk quotas and not incurring super levy penalties, a full-scale expansion strategy with milk quotas and incurring super levy penalties, and once-a-day milking until EU milk quota abolition, followed by full-scale expansion. Each discrete whole farm investment strategy was evaluated over a 15 -yr period (2013-2027) using multiple financial stability and risk indicators, including overall discounted farm business profitability, net worth change, return on investment, and financial risk. The results of this study indicate that, although associated with increased risk, dairy farm expansion will ensure the future profitability of the farm business. Within the context of EU milk quotas until 2015, the most attractive expansion strategy is to increase cow numbers while avoiding super levy fines using once-a-day milking techniques, increasing to the full capacity of the dairy farm once milk quotas are removed. In contrast, the results also indicate that dairy farms that remain static will experience a significant reduction in farm profitability in the coming year due to production cost inflation. Cash flow deficits were observed during the initial year of expansion and, therefore, rapidly expanding dairy farm businesses require a significant cash reserve to alleviate business risk during the initial year of expansion. The results of this analysis also indicate that dairy farm businesses that expand using lower cost capital investments and avoid milk quota super levy fines significantly reduce the financial risks associated with expansion.
\end{abstract}

Received November 9, 2012

Accepted January 30, 2013.

${ }^{1}$ Corresponding author: Roberta.McDonald@teagasc.ie
Key words: Ireland, expansion, new entrant dairy, cash flow

\section{INTRODUCTION}

In joining the European Community in 1973, Ireland availed of guaranteed access to European Union (EU) markets and product price supports afforded by the EU Common Agricultural Policy (CAP). As part of CAP, milk quotas were introduced in 1984 to control milk supplies, stabilizing milk price and thereby providing stable and relatively high milk prices for milk producers. As part of the 2008 Health Check review of CAP policy (European Commission, 2012) and in light of increased international pressure to remove trade barriers, the decision has been made to fully remove milk quotas in 2015. This policy change gradually increased milk quotas to create a soft landing around milk quota removal. This has resulted in a $2 \%$ quota increase in 2008, followed by a further $1 \%$ per annum increase from 2009 to 2013, with a reduction in the fat correction associated with milk fat (IPTS, 2009). Milk quota abolition is anticipated to facilitate expansion for dairy farmers to increase operational scale, thereby increasing the profitability of their farming businesses into the future (Ramsbottom et al., 2012).

From an Irish perspective, milk quota abolition has been identified as an opportunity for significant expansion in the dairy industry, owing to the low-cost comparative advantages associated with Irish grass-based production systems (Lips and Rieder, 2005; Dillon et al., 2006; van Berkum and Helming, 2006). As dairy production is the most profitable agricultural enterprise (Hennessy et al., 2011), growth within the Irish dairy industry will originate from both the expansion in milk production on existing dairy farms, as well as the entry of new entrant dairy farmers to milk production from other enterprises. To encourage new dairy enterprises, the Irish government has allocated one-quarter of the country's 1\% annual increase between 2009 and 2013 in milk quota to new entrants to dairying. Approximately 230 new dairy farm applicants have each received a 200,000 L-of-milk quota over the initial $3 \mathrm{yr}$ of the 
scheme, with a further 170 applicants anticipated to join by the year 2015 when milk quotas are abolished.

Expansion in dairy farming will require both new and existing dairy farmers to develop sustainable financial plans taking cognizance of the choice of production system, expectations for animal performance, output prices, input costs, and capital investment requirements in the longer term. The immediate challenge facing many dairy farmers is to plan farm business expansion through the period in advance of milk quota abolition in 2015. Many complex interrelated factors must be considered and simulation models have been developed to identify optimum management strategies and help understand the interactions occurring between the production system, financing structures, inflation, farm inputs and outputs, and price volatility (Parsons et al., 1983; Shalloo et al., 2004a; Geary et al., 2010). Such models also have the capacity to evaluate the feasibility of alternative management strategies, such as the optimal rate of farm business growth, rate of capital investment and allocation of resources effects on financial return, and risk to the farm on a long-term basis (Herrero et al., 1999; Shalloo et al., 2004b). The objective of the current study was to examine alternative expansion strategies for new entrant dairy farmers, taking cognizance of the implications for farm system performance, capital investment and financing costs, EU milk quota super levy exposure, overall farm business profitability, risk, and net worth change using the Moorepark Dairy Systems Model (MDSM; Shalloo et al., 2004a).

\section{MATERIALS AND METHODS}

\section{New Entrant Data Set}

The new entrant dairy farm data used in the model was based on the actual business plans and application forms from the new entrant farmers as they applied for the milk quota from the Irish Department of Agriculture, Food and the Marine (Dublin, Ireland). A detailed characterization of the existing assets and business plans and expectations of the 230 successful new entrant dairy farmers' data has been reported previously (McDonald et al., 2012) and the main characteristics are summarized in Table 1 . The average new entrant dairy farm has 58 ha of land available, which will be initially lowly stocked at 1.74 dairy livestock units per hectare. The expected annual milk production of new entrant businesses is $654 \mathrm{~kg}$ of milk solids/ha (fat plus protein kilograms), with an average milk yield of 4,954 $\mathrm{kg}$ per cow. The business plans also indicate that the majority of new entrants require a substantial loan to accompany their existing equity to develop a new dairy
Table 1. General characteristics of new entrant dairy farms (McDonald et al., 2012)

\begin{tabular}{lc}
\hline General characteristics & Average \\
\hline Age (yr) & 36 \\
Farm system characteristics & 58 \\
Land area farmed (ha) & 70 \\
Herd size (no. of cows) & 24 \\
Replacements (no. of heifers) & 1.74 \\
Stocking rate (LU/ha) & 4,950 \\
Milk yield (L/cow) & 381 \\
Milk solids (kg/cow) & 352,000 \\
Total annual milk supply (L/farm)
\end{tabular}

${ }^{1} \mathrm{LU}=$ livestock units.

enterprise. Although the average age of new entrants is 36 , almost $40 \%$ of new entrants have existing loan commitments and are hoping to secure a loan to fund the full setup costs, with the majority earmarked for the development of milking parlors, animal accommodation, and the purchase of dairy stock. The actual land area available and milk quota available was used in the model. A single farm payment is also available to the new entrants but was not used in the model due to the uncertainty of future payments due to CAP reform.

\section{Bioeconomic Model}

The MDSM (Shalloo et al., 2004a) is a stochastic budgetary simulation model. The model itself provides a comprehensive simulation framework merging the biological, physical, and economic processes into a model. The model combines the main segments of the dairy farm structure, including stock inventory and valuation, milk supply, feed requirements, utilization of land and labor, and financial and economic analysis (Shalloo et al., 2004a). The key output from the MDSM model is the estimated distribution of farm profit, determined by total receipts (milk, calves, and cull cows) less all variable costs (fertilizer, veterinary costs, AI, silage, and contractor charges), and fixed costs (maintenance and running costs, car, telephone, electricity, and insurance) based on prices deemed feasible by the projections estimated by Binfield et al. (2008). The farm financial reports originate from equations linking the total receipts, costs, and capital investment. Sensitivity analysis of each scenario was undertaken based on low and high farm investment costs, including dairy building and grassland infrastructure, in addition to alternating between low and high loan interest rates.

\section{Stochastic Budgeting}

A stochastic simulation was included in the analysis of the New Entrant expansion options. The stochastic simulation was carried out using the computer software 
@Risk version 5.5 (Palisade Corp., 2000), which works through a process of Monte Carlo sampling. Monte Carlo risk assessment is capable of specifying a probability distribution for each sensitivity parameter, draws a set of those parameters, and repeats the conventional analysis for multiple draws (Phillips and Maldonado, 1999; Phillips, 2000). An appropriately large number of simulations was run $(10,000)$ with similar input distributions, to sufficiently describe the probability distribution functions of the output (Isukapalli et al., 1998).

For the purpose of this study, the stochastic variables included in the model were milk price and interest rate. The range in milk price over the period 2005 to 2012 was calculated from observed price data obtained from the Central Statistics Office (CSO, 2011). A triangular distribution was used and the minimum, most likely, and maximum values were estimated based on the minimum and maximum milk price values between 2005 and 2012, with most likely milk price based on milk price projections (Binfield et al., 2008). As the EU has reduced the levels of market support in recent years based on World Trade Agreements (WTO, 2008), European milk price has converged with world milk prices. The minimum, most likely, and maximum values included were 20.0, 27.0, and 34.0 cents/L, respectively. Interest rate was also included as a triangular distribution based on consultation with the banking industry in Ireland. The minimum, most likely, and maximum values included were $3.5,5.5$, and $7.5 \%$, respectively. The 2 stochastic variables were assumed to be uncorrelated and were simulated together within the model.

\section{Model Assumptions}

The farm used in this analysis was the average new entrant farm: 58 ha (143.3 acres) in size, with a quota of 200,000 L of milk, which they received from the Irish government under the New Entrant Scheme (McDonald et al., 2012). The key parameters used in the MDSM are shown in Table 2, whereas the milk production characteristics used are based on Irish data for milk production across the national dairy herd for the last 20 yr (CSO, 2011). Capital investment was included based on low-cost conventional housing (€2,450/ cow) and includes all farm infrastructural requirements (such as grazing infrastructure, animal housing, and milking infrastructure; Teagasc, 2011). A contingency for capital development was included in the analysis, with a value of $15 \%$ included for all scenarios, and total equity brought into the setup of the farm was $€ 115,000$, originating from the sale of stock from the previous enterprise and the average savings as stated in the financial plans of new entrants (McDonald et al., 2012). The cost of stock was included in the model as livestock rearing costs, where growth was organic and purchased dairy cattle were valued at $€ 1,400$ per replacement heifer, when purchased just before calving, before milk quota removal and $€ 1,700$ per heifer in the year postquota to represent the expected increased demand for and value of breeding heifers within a post-quota dairy industry. These price assumptions were estimated based on industry consultation with a group of experts (NFS, 2010, 2011). The cost of finance included was based on an interest rate of $5.5 \%$ on total borrowings (Teagasc, 2011). The opportunity cost of land was included in the analysis to allow the model to rent in or lease out land that is not required for livestock production during individual years.

Table 3 highlights the key projected costs and prices used in the model based on analysis from Food and Agricultural Policy Research Institute (FAPRI)-Ireland (Binfield et al., 2008) and are subject to inflation at $3 \%$. The projected milk price was set at 27.0 cents/L based on FAPRI-Ireland projections (Binfield et al., 2008). Finally, sensitivity analysis of capital investment and financing costs was carried out using an interest rate of $3.5 \%$ and capital investment cost of $€ 1,650 /$ cow.

\section{Investment Strategies Investigated}

Six alternative expansion and infrastructural development strategies were investigated over a 15 -yr period from 2013 to 2027.

Table 2. Key default parameters used in the model

\begin{tabular}{lrrrrrr}
\hline & \multicolumn{7}{c}{ Scenario $^{1}$} \\
\cline { 2 - 6 } Item & \multicolumn{1}{c}{$\mathrm{S} 1$} & NG2 & WE3 & FNQ4 & FQ5 & OAD6 \\
\hline Land area (ha) & 58 & 58 & 58 & 58 & 58 & 58 \\
Cow numbers in yr 1 & 50 & 44 & 44 & 180 & 180 & 67 \\
Quota size (kg/farm) & 192,000 & 192,000 & 192,000 & 192,000 & 192,000 & 192,000 \\
Capital investment $(€)$ & 218,205 & 359,598 & 739,270 & 672,225 & 672,225 & 692,580 \\
Borrowings (€/cow) & 1,143 & 3,591 & 4,026 & 1,989 & 1,989 & 3,088 \\
Milk yield (kg/cow) & 5,370 & 5,314 & 5,318 & 5,415 & 5,415 & 5,150 \\
Milk solids (kg/ha) & 340 & 566 & 1,122 & 1,248 & 1,248 & 1,130 \\
\hline${ }^{1}$ S1 = static; NG2 = natural growth; WE3 = wait and expand; FNQ4 = full-scale, no-quota super levy; FQ5 &
\end{tabular}


Table 3. Key projected prices and costs variables used in the model in 2013

\begin{tabular}{lc}
\hline Item & 2013 \\
\hline Male calf price $(€)$ & 75 \\
Land opportunity cost $(€)$ & 100 or 180 if fully stocked \\
Concentrate cost $(€ / \mathrm{t})$ & 220 \\
Cull cow price $(€ /$ cow) & 400 \\
Surplus heifer price $(€ /$ heifer $)$ & 400 \\
Pre-quota & 600 \\
Post-quota & 1,400 \\
Replacement heifer price $(€ /$ heifer $)$ & 1,700 \\
Pre-quota & 0.07 \\
Post-quota & 0.27 \\
Labor cost (cents/L) & 0.29 \\
Milk price (cents/L) & \\
Super levy fine $($ cents/L) &
\end{tabular}

Static Scenario. The static (S1) scenario means that no expansion is undertaken. Fifty animals are bought and milked in yr 1 and the herd size remains static at 50 cows throughout the 15 -yr period, with surplus home-reared heifers sold. Milk quota super levy fines are avoided.

Natural Growth Scenario. The natural growth (NG2) scenario involves expansion achieved based on the natural growth of herd size over time. Fifty animals are bought and milked in yr 1, replacements are reared on the farm, and no further animals are bought in. The herd grows naturally over the following 15 -yr period. Milk quota super levy fines are avoided and surplus heifers generated before EU milk quota abolition are sold.

Wait and Expand Scenario. The wait and expand (WE3) scenario involves expansion achieved only after milk quotas are removed in yr 2. Fifty animals are bought and milked in yr 1 and no further animals are bought until yr 2 when quotas are removed. Once the quota year has passed, extra heifers are bought into the herd to bring the herd size to 180 cows as soon as possible after quotas are eliminated. Milk quota super levy fines are avoided and surplus reared heifers are sold before quota abolition.

Full-Scale, No-Quota Scenario. The full-scale, no-quota (FNQ4) scenario involves expanding to full capacity from the beginning without milk quota super levy fines. One hundred eighty animals are bought and milked from yr 1 onwards and no super levy fine is incurred for the production of milk over the allotted quota of 200,000 L. The farm buys all the animals required as soon as possible and ignores the super levy threat. All surplus heifers are sold.

Full-Scale, Quota Scenario. The full-scale, quota (FQ5) scenario involves expanding to full capacity from the beginning and incurring milk quota super levy fines. One hundred eighty animals are bought and milked from yr 1 onwards. A super levy fine is incurred for each of the first 2 yr of production for milk supply in excess of the allotted quota of 200,000 L. The farm buys all the animals required as soon as possible and incurs the super levy penalty of 29 cents/L on all milk supplied in excess of the 200,000-L milk quota for the first $2 \mathrm{yr}$ of production. All surplus heifers are sold.

Once-A-Day Milking Scenario. The once-a-day milking (OAD6) scenario involves increasing stock numbers and avoiding super levy fines by reducing milking frequency to OAD. Sixty-seven animals are bought and milked in the first $2 \mathrm{yr}$ on $\mathrm{OAD}$, thereby avoiding the super levy, and increased numbers of home-reared heifers are ready to enter the herd post-milk quotas. Milk quota super levy fines are avoided. Post-quotas, extra heifers are bought into the herd to bring the herd size to 180 cows and all cows are milked twice per day. Assumptions were based on a recent study on OAD (O'Brien et al., 2006), which reported a 26 and $20 \%$ reduction in milk volume and fat plus protein (milk solids) per cow, respectively, compared with twice-aday milking for the entire lactation, whereas both the fat and protein percentage increased (10.3 and 7.3\%, respectively).

\section{Financial Performance Evaluation}

Each expansion strategy is evaluated in terms of both profitability (profit plus net worth change) and cash flow feasibility. Profitability is evaluated over a $15-\mathrm{yr}$ term, whereas cash flow feasibility considers the ability of each expansion option to meet financial commitments and mainly concerns the initial year of expansion when debt repayment is most prominent (Shalloo et al., 2004b). The financial implications of each scenario were measured annually based on profit and cash flow, and over the complete 15-yr lifetime of the project, based on discounted net farm profit, return on investment, and overall net worth change (which includes discounted profitability and asset value). Discounted farm profit 
is the financial reward resulting from gross output exceeding the farm direct and operational expenses on an annual time step and considers the time value of profits realized.

Cash flow is the second important indicator of the financial potential of each expansion strategy and reflects the solvency of each strategy. Cash enters the farm business over time in the form of borrowed money, sales of livestock and milk, and the sale of capital assets. Cash reserves are used to meet the financial obligations of the farm, such as loan capital and interest repayments and the costs associated with milk production. The cash flow from each scenario equals the cash receipts minus cash payments over the lifetime of the investment (and is equivalent to net profit plus capital repayments minus amounts charged for depreciation, depletion, and stock inventory change). Maintaining positive cash flows (cash balance plus receipts less payments) are essential to meet the financial commitments of expanding businesses. Highly profitable expansion strategies can fail where negative cash flows typically during the initial year of expansion disrupt farm production. The cash flows of each strategy are also considered in terms of the solvency of the business in respect of repayment commitments. Each strategy was also evaluated in terms of the level of borrowings (gearing) incurred during expansion (debt per cow).

Return on investment (ROI) is a performance measure of the efficiency of each investment strategy and is calculated by dividing discounted net profits before tax and interest by the total asset value estimated based on fair market value and is displayed as a percentage. The ROI measures how effectively each expansion strategy uses capital invested to generate profit or, more generally, the income that each investment provides over the lifetime of investment. The ROI will be greater for investments requiring lower levels of capital investment or delivering greater net profits ceteris paribus.

\section{RESULTS}

The impact of each scenario on cow numbers and milk production per cow and per hectare are displayed in Table 2.

\section{Profit}

The trends in discounted net profit over a $15-y r$ period for expansion scenarios S1 to OAD6 are displayed in Table 4. The FNQ4 scenario achieved the greatest cumulative discounted net profit $(€ 590,339)$ over the 15 -yr period, as high levels of profitability were realized early in the lifetime of the project and no quota super levy penalty fines were incurred. In contrast, the lowest overall discounted net profit was achieved with the S1 and NG2 scenarios (€65,465 and $€ 87,485$, respectively). The low overall profitability of S1 was based on static and low milk receipts over the entire period of the project while costs increased. Similarly, the NG2 option also realized a low overall discounted profitability due to low milk output during the initial year of the project and increased capital costs to facilitate the growing herd. The intermediate profitability of FQ5 (€251,321) was a consequence of incurring large super levy penalties during the $2 \mathrm{yr}$ in advance of milk quota removal. Where super levy fines exist, OAD6 achieved the greatest profit $(€ 479,977)$ and WE3 was the next most profitable strategy $(€ 415,037)$, as both strategies avoided super levy fines for the first 3 quota years and achieved maximum output in the post-quota year thereafter. The WE3 scenario achieved a somewhat lower profit over the 15 yr compared with OAD6, as more animals must be purchased post-quotas (in yr 3 ) due to the smaller herd size during the first 2 quota years (yr 1 to 2 ).

\section{Cash Flow}

A summary of the annual cash flow projections are presented in Figure 1. Cash flow represents the availability of money to meet day-to-day financial obligations and without which a business cannot function. All scenarios incurred a negative cash flow during the first year of the project, whereas S1, NG2, and FNQ4 generated a cash surplus during yr 2. In contrast, WE3, FQ5, and OAD6 remained in negative cash flow until yr 3, although WE3 returned to negative cash flows during yr 6.

\section{New Worth and ROI}

Expansion strategy, capital investment level, and interest rate have a significant effect on the net worth created during the lifetime of the investment when owned net asset values (assets less liabilities) are considered in addition to net profitability (Table 5). Similar to net profitability, the FNQ4 scenario achieved the greatest net worth $(€ 1,040,789)$ when the net residual value of assets $(€ 450,450)$ was added to net discounted profitability (€590,339). Within the context of milk quotas, the highest overall net worth was consistently achieved with OAD6 (€930,427) and WE3 $(€ 865,487)$, whereas S1 realized the lowest net worth (€190,590).

The effect of capital investment on the total ROI of each scenario investigated is illustrated in Table 6 . The greatest ROI over the lifetime of the project at an average investment and interest rate; was achieved by FNQ4 (3.4\%), whereas S1 and NG2 were lowest (0.6 


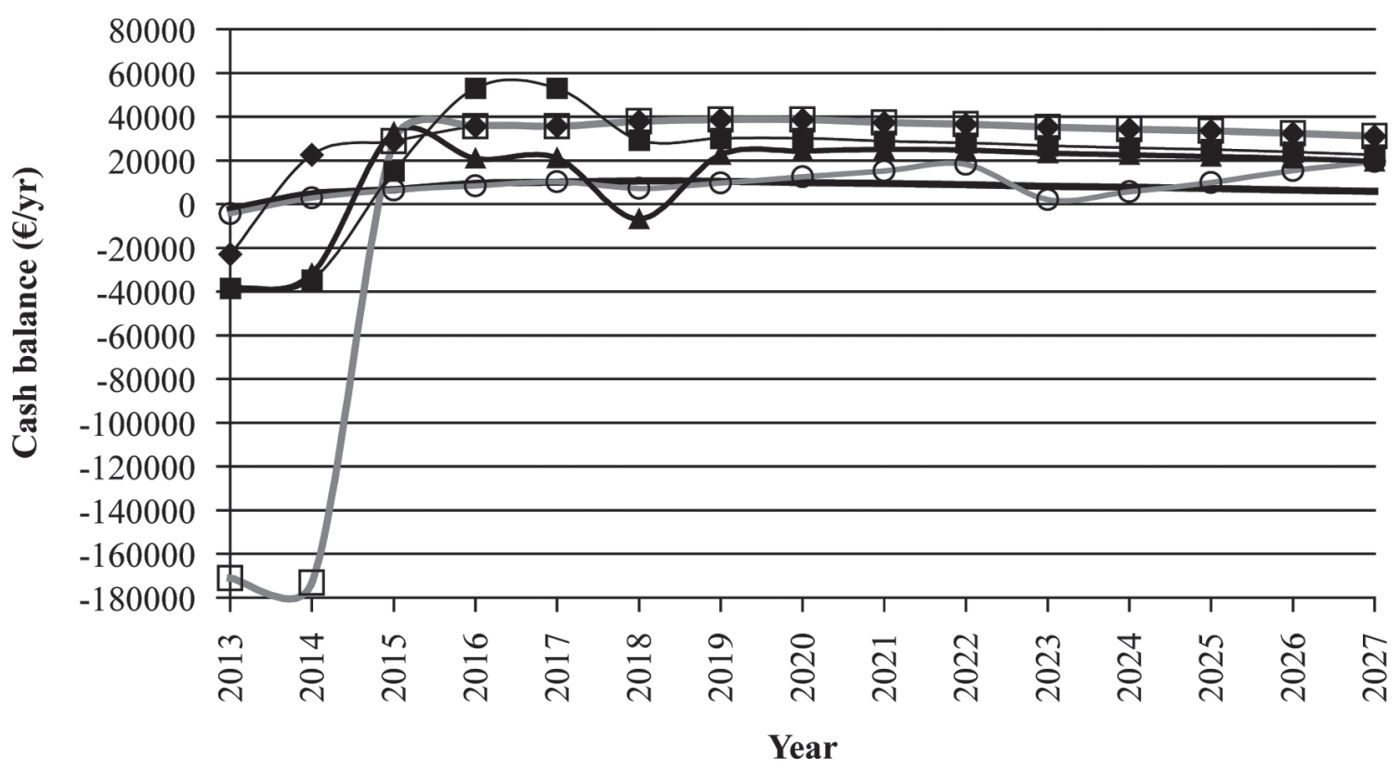

Figure 1. The effect of 6 alternative expansion scenarios [static (S1; thick black line), natural growth (NG2; O), wait and expand (WE3; $\mathbf{\Delta}$ ), full expansion, no quota (FNQ4; $\bullet$ ), full expansion, quota (FQ5; $\square$ ), and once-a-day (OAD6; $\mathbf{a})$ on annualized cash flows over a 15-yr period.

and $1.1 \%$, respectively) and WE3, FQ5, and OAD6 were intermediate $(2.8,2.2$, and $3.0 \%$, respectively).

\section{Sensitivity Analysis}

The impact of investment costs and interest rate on net margin is dependent on the expansion strategy chosen (Table 5). Consequently, the discounted profitability of low-cost expansion was increased by $68,100,38$, 27, 63, and $33 \%$ for S1, NG2, WE3, FNQ4, FQ5, and OAD6, respectively, whereas overall net worth increased by $18,56,14,12,18$, and $13 \%$, respectively, compared with average capital investment costs. Over the 15-yr time period, low-cost capital investment increased cash flows for S1, NG2, WE3, FNQ4, and OAD6, respectively, whereas the cash-flow deficit associated with FQ5 at average investment costs was converted into a cash surplus. Similarly, low-cost investment generated cash surpluses in each year of both S1 and NG2 scenarios and FNQ4 also achieved positive cash flows from yr 2 onwards. Low-cost capital investment also had an important impact on cash flows during the 2

Table 4. Trends in discounted profit over 15 yr across all 6 farm expansion scenarios

\begin{tabular}{|c|c|c|c|c|c|c|}
\hline \multirow[b]{2}{*}{ Yr } & \multicolumn{6}{|c|}{ Expansion scenario $^{1}$} \\
\hline & S1 & NG2 & WE3 & FNQ4 & FQ5 & OAD6 \\
\hline $2013^{2}$ & $-6,473$ & $-8,415$ & $-42,543$ & $-17,528$ & $-165,849$ & $-40,895$ \\
\hline $2014^{2}$ & 807 & $-1,037$ & $-33,449$ & 28,716 & $-161,981$ & $-35,103$ \\
\hline 2015 & 2,783 & 2,808 & 29,765 & 35,632 & 35,632 & 14,339 \\
\hline 2016 & 5,574 & 4,762 & 19,172 & 42,517 & 42,517 & 50,143 \\
\hline 2017 & 6,287 & 6,592 & 19,928 & 43,031 & 43,031 & 49,989 \\
\hline 2018 & 6,884 & 1,513 & 14,673 & 45,548 & 45,548 & 42,487 \\
\hline 2019 & 6,841 & 3,969 & 41,292 & 46,677 & 46,677 & 43,938 \\
\hline 2020 & 6,459 & 6,586 & 43,630 & 47,064 & 47,064 & 44,645 \\
\hline 2021 & 6,152 & 8,854 & 45,190 & 46,497 & 46,497 & 44,396 \\
\hline 2022 & 5,850 & 11,393 & 45,939 & 46,311 & 46,311 & 44,524 \\
\hline 2023 & 5,312 & 3,115 & 45,805 & 45,708 & 45,708 & 44,233 \\
\hline 2024 & 5,162 & 6,352 & 46,093 & 45,473 & 45,473 & 44,305 \\
\hline 2025 & 4,928 & 9,954 & 46,453 & 45,324 & 45,324 & 44,457 \\
\hline 2026 & 4,538 & 14,011 & 46,565 & 44,942 & 44,942 & 44,371 \\
\hline 2027 & 4,360 & 17,030 & 46,525 & 44,426 & 44,426 & 44,145 \\
\hline Total & 65,465 & 87,485 & 415,037 & 590,339 & 251,321 & 479,977 \\
\hline
\end{tabular}

${ }^{1} \mathrm{~S} 1$ = static; NG2 = natural growth; WE3 = wait and expand; FNQ4 = full-scale, no-quota super levy; FQ5 = full-scale with quota super levy; OAD6 = once-a-day milking.

${ }^{2}$ Milk quotas. 
Table 5. The effect of capital investment cost and interest rate on the profitability and net worth of 6 alternative expansion scenarios over a 15 -yr period

\begin{tabular}{|c|c|c|c|c|c|c|c|}
\hline Scenario $^{1}$ & $\begin{array}{l}\text { Total } \\
\text { receipts }(€)\end{array}$ & $\begin{array}{l}\text { Variable } \\
\text { costs }(€)\end{array}$ & $\begin{array}{l}\text { Fixed costs } \\
(€)\end{array}$ & $\begin{array}{l}\text { Net profit } \\
\quad(€)\end{array}$ & $\begin{array}{l}\text { Residual } \\
\text { debt }(€)\end{array}$ & $\begin{array}{l}\text { Residual } \\
\text { assets }(€)\end{array}$ & $\begin{array}{l}\text { Net worth } \\
\quad(€)\end{array}$ \\
\hline \multicolumn{8}{|c|}{$\begin{array}{l}\text { Average cost investment and average interest rate } \\
(€ 2,450 / \text { cow and } 5.5 \% \text { p.a. })^{2}\end{array}$} \\
\hline NG2 & $1,615,079$ & 503,884 & $1,023,709$ & 87,485 & 139,958 & 289,335 & 236,862 \\
\hline WE3 & $3,361,357$ & $1,126,537$ & $1,819,784$ & 415,037 & 0 & 450,450 & 865,487 \\
\hline FNQ4 & $3,849,268$ & $1,294,041$ & $1,964,889$ & 590,339 & 0 & 450,450 & $1,040,789$ \\
\hline \multicolumn{8}{|c|}{$\begin{array}{l}\text { Low cost investment and average interest rate } \\
(€ 1,650 / \text { cow and } 5.5 \% \text { p.a.) }\end{array}$} \\
\hline $\mathrm{S} 1$ & $1,009,014$ & 245,568 & 653,656 & 109,790 & 0 & 115,125 & 224,915 \\
\hline NG2 & $1,615,079$ & 503,884 & 936,279 & 174,916 & 90,328 & 285,805 & 370,392 \\
\hline WE3 & $3,361,357$ & $1,126,537$ & $1,660,213$ & 574,608 & 0 & 414,450 & 989,058 \\
\hline FNQ4 & $3,849,268$ & $1,294,041$ & $1,805,318$ & 749,910 & 0 & 414,450 & $1,164,360$ \\
\hline FQ5 & $3,849,268$ & $1,633,058$ & $1,805,318$ & 410,892 & 0 & 414,450 & 825,342 \\
\hline WE3 & $3,361,357$ & $1,126,537$ & $1,715,439$ & 519,381 & 0 & 450,450 & 969,831 \\
\hline FNQ4 & $3,849,268$ & $1,294,041$ & $1,853,199$ & 702,028 & 0 & 450,450 & $1,152,478$ \\
\hline FQ5 & $3,849,268$ & $1,633,058$ & $1,853,199$ & 363,011 & 0 & 450,450 & 813,461 \\
\hline OAD6 & $3,416,801$ & $1,123,550$ & $1,711,156$ & 581,654 & 0 & 450,450 & $1,032,104$ \\
\hline
\end{tabular}

${ }^{1} \mathrm{~S} 1$ = static; NG2 = natural growth; WE3 = wait and expand; FNQ4 = full-scale, no-quota super levy; FQ5 = full-scale with quota super levy; OAD6 = once-a-day milking.

${ }^{2}$ p.a. $=$ per annum.

initial years before milk quota removal, increasing cash surplus for S1, NG2, and FNQ4 while reducing the cash flow deficits associated with WE3, FQ5, and OAD6. Similarly, the profitability associated with expansion at a low interest rate was increased by $26,49,25,19,44$, and $21 \%$ for S1, NG2, WE3, FNQ4, FQ5, and OAD6, respectively, whereas overall net worth was increased by $9,29,12,11,16$, and $11 \%$, respectively, compared with average interest rates. Where expansion was achieved using low-cost capital investment, ROI was further increased to $0.7,1.3,3.2,3.9,2.6$, and $3.4 \%$ for S1, NG2, WE3, FNQ4, FQ5, and OAD6, respectively (see Table 6).

\section{Stochastic Evaluation}

Figure 2 shows a cumulative density function of the influence of variation in milk price and interest rate on the distribution of discounted farm profit plus net worth change for options S1, NG2, WE3, FNQ4, FQ5, and OAD6. The $90 \%$ confidence intervals (5-95\%) were $€ 31,617$ to $€ 350,130$, €122,146 to €632,070, €337,684 to $€ 1,391,334, € 464,795$ to $€ 1,581,054, € 98,992$ to $€ 1,299,302$, and $€ 399,914$ to $€ 1,461,695$ for S1, NG2, WE3, FNQ4, FQ5, and OAD6, respectively.

\section{DISCUSSION}

In evaluating alternative expansion options for any business, it is important to consider multiple indicators (Thomas et al., 1997; Ferris and Malcolm, 1999; StPierre et al., 2000) taking both financial return and risk into consideration. Ferris and Malcolm (1999) suggested that where discrete whole-farm alternative investment strategies are being considered, similar to those in the

Table 6. The effect of capital investment cost on the total return on investment (ROI; \%) of 6 alternative expansion scenarios over a 15 -yr period

\begin{tabular}{lccccccc}
\hline & & \multicolumn{5}{c}{ Scenario investigated $^{1}(\%)$} \\
\cline { 3 - 7 } $\begin{array}{l}\text { Capital investment } \\
(€ / \text { cow })\end{array}$ & $\begin{array}{c}\text { Interest rate } \\
\text { (\% per annum) }\end{array}$ & $\mathrm{S} 1$ & NG2 & WE3 & FNQ4 & FQ5 & OAD6 \\
\hline 2,450 & 5.5 & 0.6 & 1.1 & 2.8 & 3.4 & 2.2 & 3.0 \\
1,650 & 5.5 & 0.7 & 1.3 & 3.2 & 3.9 & 2.6 & 3.4 \\
\hline${ }^{1}$ S1 = static; NG2 = natural growth; WE3 = wait and expand; FNQ4 = full-scale, no-quota super levy; FQ5 \\
$=$ full-scale with quota super levy; OAD6 = once-a-day milking.
\end{tabular}




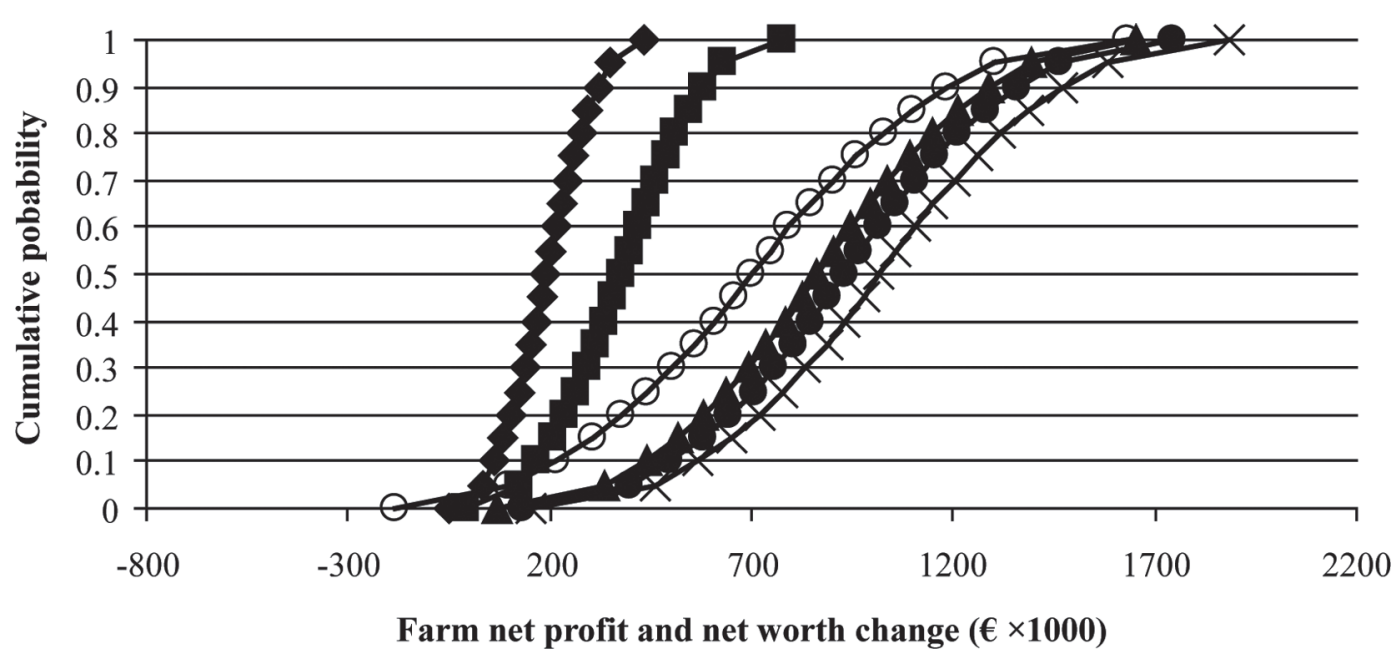

Figure 2. Cumulative probability distribution showing the influence of milk price and interest rate on discounted net profit plus net worth for the 6 scenarios at an investment rate of $€ 2,450 /$ cow over a 15 -yr period. $\boldsymbol{\square}=$ static (S1); $=$ natural growth (NG2); $\boldsymbol{\Delta}=$ wait and expand (WE3); $\mathrm{X}=$ full-scale, no-quota super levy (FNQ4); $\mathrm{O}=$ full-scale with a quota super levy (FQ5); $\bullet$ once-a-day (OAD6).

current study, the optimum method of evaluation must also consider time value profitability, financial feasibility, and net worth change associated with each investment over a reasonable planning period. In the current analysis, each of the 6 scenarios investigated was considered in terms of financial feasibility (based on cash flows, debt-servicing ability, and variability in key parameters) and net financial impact (using indicators such as discounted net profit, return on investment, and the net worth change). The multidimensional nature of such analysis is important to accurately identify both the return and risk associated with each expansion strategy and, consequently, the optimum scenario must be considered in terms of the overall combination of these factors (Thomas et al., 1997; St-Pierre et al., 2000; Shalloo et al., 2004b).

The business environment for dairying is changing rapidly and the importance of strategic business planning and goal setting to position the farm business for profitable milk production in the future is widely acknowledged (Bell, 2009). In a recent survey analysis of the future intentions of a sample of Irish dairy farmers, O'Donnell et al. (2011) reported that one-third of farmers surveyed planned to remain static due to uncertainty about the future. Similar to other recent studies (Hadley et al., 2002; Shalloo et al., 2004b; Leddin et al., 2011; Ramsbottom et al., 2012), the current analysis advocates increased operational scale as a key strategy to protect the future profitability of the farm business compared with the performance of the system under a status quo (S1). At average capital investment costs and interest rates (€2,450/cow and $5.5 \%$ p.a., respectively), and while increasing debt and reducing cash flows, all expansion strategies exhibited a positive discounted net profit and net worth over the 15-yr period investigated and increased annual discounted net profitability over time compared with the S1 scenario. The low overall productivity, profitability, and asset growth associated with both S1 and NG2 scenarios within this study was consistent, regardless of investment cost and interest rate and indicates that, although relatively low risk and devoid of large cash flow deficits, neither scenario provides a financially feasible production system for the future. In a previous study, Shalloo et al. (2004b) also observed significant financial returns from expansion, particularly where low-cost capital investment was used. The same analysis also concluded that dairy farms that remained static during the era of milk quotas would experience significant erosion in farm income over time unless new production technologies could be adopted to increase production efficiency.

In the current analysis, profitability was measured by discounted net farm profit, net worth change over time, and ROI (excluding capital appreciation) within each expansion strategy. The higher relative ROI associated with large-scale expansion (WE3, FNQ4, FQ5, and OAD6) has been observed previously (Lagura and Ronan, 2009) and is indicative of a greater efficiency of resource use within expanding production systems. The relatively low overall ROI across all expansion strategies (ranging from 0.6 to $3.9 \%$ ) is similar to that reported from other pasture-based production systems (Neal, 2004,; Thorrold and Doyle, 2007; Lagura and Ronan, 2009) and is indicative of the capital intensive nature of land ownership in modern pasture-based production systems.

Increasing operational scale usually requires significant capital investment and, together with the associ- 
ated increase in financing costs, has a substantial impact on the solvency and risk position of an expanding capital intensive dairy business (St-Pierre et al., 2000). Negative cash flows occur due to an imbalance between cash inflows and cash outflows and require monthly cash flow budgeting and contingency funds to meet short-term business commitments (Connolly, 2011; Ministry of Agriculture, 2012). In the current analysis, lower capital investment costs and interest rates significantly increased net discounted profitability and net worth and improved cash flows during the 15-yr period. Although the ranking of expansion strategies according to profitability was consistent regardless of capital investment cost or interest rate, these results indicate that avoiding overcapitalization, high interest rates and super levy fines are among the underlying principles to ensure solvency of the farm business. Similarly, Hadley et al. (2002) noted that although modernizing facilities improved productivity and profitability, overcapitalization was frequently responsible for poor financial results among expanding US dairy herds.

The NG2 and WE3 scenarios within the study represent cautious expansion strategies that avoid the risk of milk quota super levy fines and significant negative cash flows. In the case of NG2, the discounted net profit increased gradually with the natural increase in herd size from replacements produced within the herd and where additional infrastructure was built as required. Similar to S1, NG2 resulted in low milk output and, consequently, low profitability during the earlier year of the project; however, the overall profitability of NG2 was considerably less than S1 due to additional capital investment costs associated with expansion in advance of the increase to full-scale milk production. This phased expansion strategy whereby additional capital investment precedes increased milk production places additional pressure on both profitability and cash flow during the initial low-productivity year of expansion. The WE3 scenario delayed full-scale expansion until after milk quota abolition (yr 4) and resulted in low productivity levels, a net financial loss and cash-flow deficits during the initial $2 \mathrm{yr}$ of expansion. Although the feasibility of WE3 was reduced due to poor financial performance during the initial year, the overall discounted net profitability and overall net worth of WE3 was significantly higher than that of either S1 or NG2.

The FNQ4 and FQ5 scenarios represent the implications of full-scale milk production expansion from yr 1 in the absence or presence of EU milk quota super levy penalties. Although FNQ4 is not currently possible due to the presence of EU milk quotas, the consistently high overall discounted profitability, total net worth, and ROI of FNQ4 coupled with cash surpluses from yr 2 onwards is indicative of the potential financial rewards associated with full-scale milk production expansion within an environment free from the confines of EU milk quotas. In contrast, FQ5 reflects the detrimental effects of full-scale milk production expansion within the current milk quota system. Although resulting in a high overall net worth over the 15-yr period, the low overall net discounted profitability and severe net losses and cash-flow deficits incurred from super levy penalties during the 2 initial years of expansion make this scenario unfeasible, as the business would be insolvent in the initial year of the project.

In the interim to milk quota abolition, the most attractive expansion strategy in terms of net worth growth and ROI is to increase cow numbers while avoiding super levy fines using the OAD6 strategy, increasing to full capacity of the dairy farm once milk quotas are removed. Although milking OAD reduces milk volume per cow, milk solids volume per cow, and milk receipts (due to reduced volume), it does result in increased milk solids percentage (O'Brien et al., 2006), increased labor productivity, and reduced milking parlor expenses (Clark et al., 2006). Indeed, the superior profitability of OAD6 over the WE3 strategy (increased total discounted net profit by $16 \%$ and net worth by $8 \%$ ) indicates the additional advantage of increasing owned stock numbers on dairy farms in advance of milk quota removal to facilitate cost-efficient and rapid expansion in milk production post-quotas.

The cumulative probability distributions within the current analysis identify the stochastically dominant option. First-degree stochastic dominance implies that the risk preference of the individual is not taken into account when evaluating the risk options (Shalloo et al., 2004b). Ultimately, the balance of risk and return is central to strategic decision making (Bell, 2009; Malcolm et al., 2012). The choice of expansion strategy will be dictated by the individual farmer's attitude to risk in addition to the potential return from alternative expansion strategies. These results indicate that the spread in net farm profit plus net worth is greatest for options of rapid or immediate growth, without incurring super levy fines, whereas static or natural growth options consistently realize reduced farm profits. Farmers are usually cautious toward risk (Harrington and Niehaus, 1999) and not solely influenced by profit maximization (Vanclay, 2004). Indeed, Shalloo et al. (2004b) previously indicated that milk producers who are highly risk adverse will choose slower growth, lower-returning scenarios (S1 and NG2) in preference to riskier rapid expansion options. As the cumulative density functions for each of these 2 scenarios cross over, second-degree stochastic dominance is used to identify the more favorable scenario and, in this case, indicates the superiority of S1 over NG2. 
The current analysis indicates that expansion in milk production during the transition to milk quota removal will increase business risk as fluctuating and uncertain cash flows reduce the businesses ability to meet prior claims (primarily debt servicing). The severe cash-flow deficits observed during the initial year of expansion within this study suggest that rapidly expanding dairy farm businesses require a significant cash reserve to alleviate the business risks associated with the initial year of large-scale expansion. Recent studies have indicated that the additional financial pressures during expansion will be compounded by a general reduction in the efficiency of milk production within expanding farm businesses (Ramsbottom et al., 2012), placing further pressures on cash flow.

\section{CONCLUSIONS}

In a comparison of 6 alternative expansion strategies over a period of $15 \mathrm{yr}$, the results of this study indicate that although it increases business risk and results in cash-flow deficits, dairy farm expansion will protect the future profitability of the farm business. Within the context of EU milk quotas until quota abolition in 2015 , the most attractive expansion strategy in terms of overall net worth growth and return on invested capital is to increase cow numbers while avoiding super levy fines using OAD milking (OAD6), increasing to full capacity once milk quotas are removed. The severe cash-flow deficits observed during the initial year of expansion suggest that rapidly expanding dairy farm businesses require a significant cash reserve to alleviate business risk during the initial year of expansion. Furthermore, these results show that expanding farm businesses that realize lower capital investment costs and interest rates and avoid milk quota super levy fines significantly reduce the financial risks associated with expansion by increasing net profitability, minimizing cash flow deficits, and maximizing net worth growth.

\section{ACKNOWLEDGMENTS}

The authors acknowledge the participating new entrant dairy farmers for their assistance and the financial support of Allied Irish Banks p.l.c. (Dublin, Ireland) for this research.

\section{REFERENCES}

Bell, R. 2009. Long-term strategic planning of dairy businesses. Pages 25-39 in Proc. 27th West Canadian Dairy Seminar (WCDS): Advances in Dairy Technology. Vol. 21. Red Deer, Alberta, Canada.

Binfield, J., T. Donnellan, K. Hanrahan, and P. Westhoff. 2008. FAPRI-Ireland baseline 2008 outlook for EU and Irish agriculture.
Page 15 in Economic Projections for Irish Agriculture. Food and Agricultural Policy Research Institute (FAPRI)-Ireland.

Clark, D. A., C. V. C. Phyn, M. J. Tong, S. J. Collis, and D. E. Dalley. 2006. A systems comparison of once- versus twice-daily milking of pastured dairy cows. J. Dairy Sci. 89:1854-1862.

Connolly, K. 2011. Getting full value from a cash flow budget. Pages 1-6 in Farm Management: Recording Cash Flow Budgeting. Teagasc, Dublin, Ireland.

CSO (Central Statistics Office). 2011. Principal Statistics in Relation to Agriculture. CSO, Cork, Ireland.

Dillon, P., T. Hennessy, L. Shalloo, F. Thorne, and B. Horan. 2006 Future outlook for the Irish dairy industry: A study of international competitiveness, influence of international trade reform and requirement for change. Int. J. Dairy Technol. 61:16-29.

European Commission. 2012. Agriculture and Rural Development: The History of the CAP (online). Accessed Aug. 7, 2012. http:// ec.europa.eu/agriculture/cap-history/index_en.htm.

Ferris, A., and B. Malcolm. 1999. Sense and nonsense in dairy farm management economic analysis. Pages 1-31 in Proc. 43rd Annual Australian Agricultural and Resource Economics Society (AARES) Conference, Christchurch, New Zealand. AARES, The Australian National University, Canberra.

Geary, U., N. Lopez-Villalobos, D. J. Garrick, and L. Shalloo. 2010. Development and application of a processing model for the Irish dairy industry. J. Dairy Sci. 93:5091-5100.

Hadley, G. L., S. B. Harsh, and C. A. Wolf. 2002. Managerial and financial implications of major dairy farm expansions in Michigan and Wisconsin. J. Dairy Sci. 85:2053-2064.

Harrington, S. E., and G. R. Niehaus. 1999. Risk Management and Insurance. 2nd ed. McGraw/Hill, Boston, MA.

Hennessy, T., B. Moran, A. Kinsella, and G. Quinlan. 2011. National Farm Survey 2010. Teagasc Agricultural Economics \& Farm Surveys Department, Athenry, Co. Galway, Ireland

Herrero, M., R. H. Fawcett, and J. B. Dent. 1999. Bio-economic evaluation of dairy farm management scenarios using integrated simulation and multiple-criteria models. Agric. Syst. 62:169-188.

IPTS (Institute for Prospective Technological Studies). 2009. Economic Impact of the Abolition of Milk quota Regime - Regional analysis of the milk production in the EU. Page VIII. EuroCARE $\mathrm{GmbH}$, Bonn, Germany.

Isukapalli, S. S., A. Roy, and P. G. Georgopoulos. 1998. Stochastic response surface methods (SRSMs) for uncertainty propagation: Application to environmental and biological systems. Risk Anal. 18:351-363.

Lagura, E. and G. Ronan. 2009. How Profitable is Farm Business in Australia? An Interpretation of ABARE broadacre and dairy industries' farm performance data and some implications for public policy. Australian Agricultural and Resource Economics Society. Adelaide, Australia. Accessed Nov. 7, 2012. http://www.agrifood. info/connections/2009/Lagura_Ronan.html.

Leddin, C. M., J. W. Heard, L. R. Malcolm, K. A. Tarrant, C. K. M. Ho, and W. J. Wales. 2011. Evaluating options to increase profitability on a dairy farm in southwest Victoria, Australia. In 18th International Farm Management Congress, Methven, Canterbury, New Zealand. International Farm Management Association, Whittlesford, Cambridge, UK.

Lips, M., and P. Rieder. 2005. Abolition of raw milk quota in the European Union: A CGE analysis at the member country level. J. Agric. Econ. 56:1-17.

Malcolm, B., C. K. M. Ho, D. P. Armstrong, P. T. Doyle, K. A. Tarrant, J. W. Heard, C. M. Leddin, and W. J. Wales. 2012. Dairy directions: A decade of whole farm analysis of dairy systems. Australas. Agribusiness Rev. 20:39-58.

McDonald, R., K. Pierce, R. Fealy, P. Savage, and B. Horan. 2012. Characteristics, intentions and expectations of new entrant dairy farmers entering the Irish dairy industry through the New Entrant Scheme. In Irish Agricultural Research Forum. Vol. 2012. Teagasc, Tullamore, Co. Offaly, Ireland.

Ministry of Agriculture. 2012. Saskatchewan Ministry of Agriculture Module 7: Cash flow statement analysis. Pages 14-15 in Compre- 
hensive Guide to Farm Financial Management. Ministry of Agriculture, Regina, SK, Canada.

Neal, M. 2004. Risk and Return in New Zealand dairying: Where have we been? Page 13 in Dexcelink. Vol. Autumn 2004. Dexcel, Hamilton, New Zealand.

NFS. 2010. National Farm Survey 2009. T. Hennessy, B. Moran, A. Kinsella, and G. Quinlan, ed. Teagasc Rural Economy Research Centre, Athenry, Galway, Ireland.

NFS. 2011. National Farm Survey 2010. T. Hennessy, B. Moran, A. Kinsella, and G. Quinlan, ed. Teagasc Rural Economy Research Centre, Athenry, Galway, Ireland.

O'Brien, B., L. Shalloo, S. O'Donnell, A. M. Butler, D. Gleeson, and K. O'Donovan. 2006. Labour and economic aspects of dairy farming. Proc. 57th Annual Meeting of the European Association for Animal Production, Antalya, Turkey. European Federation for Animal Science, Rome, Italy

O'Donnell, S., B. Horan, A. M. Butler, and L. Shalloo. 2011. A survey of the factors affecting the future intentions of Irish dairy farmers. J. Agric. Sci. 149:647-654.

Palisade Corp. 2000. @Risk advanced risk analysis for spreadsheets. Palisade Corp., Newfield, NY.

Parsons, A. J., E. U. Leafe, B. Collett, P. D. Penning, and J. Lewis. 1983. The physiology of grass production under grazing II. Photosynthesis, crop growth and animal intake of continuously-grazed swards. J. Appl. Ecol. 20:127-139.

Phillips, C. V. 2000. Applying fully articulated distributions. Am. J. Epidemiol. 151:S41.

Phillips, C. V., and G. M. Maldonado. 1999. Using Monte Carlo methods to quantify multiple sources of error in studies. Am. J. Epidemiol. 149:S17.

Ramsbottom, G., A. R. Cromie, B. Horan, and D. P. Berry. 2012. Relationship between dairy cow genetic merit and profit in commercial Irish spring calving dairy farms. Animal 6:1031-1039.
Shalloo, L., P. Dillon, M. Rath, and M. Wallace. 2004a. Description and validation of the Moorepark Dairy System Model. J. Dairy Sci. 87:1945-1959.

Shalloo, L., P. Dillon, M. Rath, and M. Wallace. 2004b. The Luxembourg common agricultural policy reform agreement: Irish Dairy farmers development options. J. Farm Management 12:91-104.

St-Pierre, N. R., D. Shoemaker, and L. R. Jones. 2000. The next $\$ 120,000$ : A case study to illustrate analysis of alternative farm investments in fixed assets. J. Dairy Sci. 83:1159-1169.

Teagasc. 2011. Teagasc Greenfield Dairy Programme. In Moorepark Dairy Levy Research Update Series 15. Teagasc, Cork, Ireland.

Thomas, C. V., M. A. DeLorenzo, D. R. Bray, R. N. Weldon, R. A. Bucklin, and J. G. Martin III. 1997. A Stochastic economic analysis of large herringbone and parallel milking parlors. J. Dairy Sci. $80: 2418-2428$

Thorrold, B. S., and P. T. Doyle. 2007. Nature or Nurture-Forces shaping the current and future state of dairy farming in New Zealand and Australia. Pages 450-460 in Meeting the Challenges for Pasture-Based Dairying. Proc. 3rd Australasian Dairy Science Symposium. D. F. Chapman, D. A. Clarke, K. L. MacMillan, and D. P. Nation, ed. National Dairy Alliance, Melbourne, Australia.

van Berkum, S., and J. F. M. Helming. 2006. European dairy policy in the years to come: Impact of quota abolition on the dairy sector. LEI Wageningen UR, The Hague, the Netherlands.

Vanclay, F. 2004. Social principles for agricultural extension to assist in the promotion of natural resource management. Aust. J. Exp. Agric. 44:213-222.

WTO (World Trade Organization). 2008. The WTO Agreement Series 3 Agriculture. In The WTO Agreement Series 3 Agriculture. WTO, Geneva, Switzerland. Accessed Nov. 7, 2012. http://www. wto.org/english/res_e/booksp_e/agrmntseries3_ag_e.pdf. 